\title{
När kom kapitalismen till Tornedalen?
}

\author{
Tage Alalehto
}

SAMMANDRAG: Tage Alalehto undersöker i denna artikel när kapitalismen kom till Tornedalen. Han utgår från lokalhistoriska källor om specifika byar i Tornedalen samt offentlig historisk statistik över hur avsättning, omsättning och vinst har utvecklats inom sektorerna jordbruk, skogsbruk och offentliga tjänster. Den bild som framträder är att en omfattande självhushållningsekonomi var dominerande långt in på 1900-talet. Ett mått av kapitalistisk produktion förekom inom skogsbruket mellan 1950- och 1980-talet, men som en följd av 1950-talets strukturomvandling, rationaliseringarna inom skogsbruket samt en frånvarande industristruktur i övrigt ersattes arbetsmarknaden till viss del av kommunala och statliga tjänster. I det stora hela blev dock Tornedalen en avfolkningsbygd. Arbetskraften sökte sig till andra regioner, så att Tornedalen kom att fungera som en geografisk arbetskraftsreserv.

NYCKELORD: kapitalism; Tornedalen; reservgeografi; reservarbetskraft; jordbruk; skogsbruk; offentliga tjänster.

PUBLICERINGSHISTORIK: Originalpublicering.

TAGE ALALEHTO är docent i sociologi vid Umeå universitet.

E-POSTADRESS: tage.alalehto@umu.se

FÖRSLAG PÅ KÄLLANGIVELSE:

Alalehto, Tage (2019) "När kom kapitalismen till Tornedalen?", i Arkiv. Tidskrift för sambällsanalys, nr Io, s. 87-III.

DoI: https://doi.org/IO.I3068/2000-6217.I0.4

(C) Tage Alalehto/Arkiv förlag \& tidskrift 2019 (publicerad 28 maj 20ı19)

Artikeln distribueras enligt en upphovsrättslicens från Creative Commons:

Erkännande-Ickekommersiell-IngaBearbetningar 3.o Unported, som medger fri ickekommersiell användning och spridning i oförändrat skick så länge källan anges. 
Arkiv. Tidskrift för samhällsanalys är en sakkunniggranskad vetenskaplig tidskrift för samhällsvetenskap och historia. Samtliga artiklar publiceras fritt tillgängliga på:

$$
\text { www.tidskriftenarkiv.se }
$$

Beständig länk, DOI: https://doi.org/IO.13068/2000-62I7

Den här artikeln finns tillgänglig i följande format:

PDF: via beständig länk, DoI: https://doi.org/IO.13068/2000-62I7.IO.4

TRYCK: ingår i bokutgåva av numret, ISBN: 978 9I 79243272

Grafisk utformning och sidnumrering är identisk i pdf och tryck.

Samtliga artiklar i nr ıo (2019) nås via beständig länk, DOI: https://doi.org/IO.I3068/2000-6217.IO

Arkiv. Tidskrift för sambällsanalys

ISSN: 2000-6217 (för elektronisk resurs)

ISSN: 2000-6225 (för tryckta nummer)

ges ut av

Stiftelsen Arkiv för främjande och spridning av samhällsvetenskaplig och historisk forskning

genom

Arkiv förlag \& tidskrift

Box 1559

SE-22I OI Lund

BESÖK: L Gråbrödersg 3 c, ipg

TEL: 046-I3 3920

ARKIV FÖRLAG: arkiv@arkiv.nu·www.arkiv.nu

TIDSKRIFTEN ARKIV: red@tidskriftenarkiv.se.www.tidskriftenarkiv.se

ANSVARIg UTGIVARE \& CHEFREDAKTÖR: Sven Hort

AdMinistrativ Redaktör: David Lindberg

Redaktörer: Paavo Bergman, Per Dannefjord, Lisa Kings,

Zhanna Kravchenko, Anna-Maria Sarstrand Marekovic 


\section{När kom kapitalismen till Tornedalen?}

TAGE ALALEHTO

\section{Inledning}

Rubrikens något udda och märkliga fråga kan te sig onödig att ställa. Vad spelar det egentligen för roll när Tornedalen blev dominerad av en kapitalistisk produktionsordning? Det räcker väl med det faktum att det blev det. Ja, det kanske räcker om man antar följande premisser: Kapitalismen (A) som produktionsordning dominerar i Västeuropa (B). Sverige (C) ingår i Västeuropa. Tornedalen (D) ingår i Sverige. Alltså: Kapitalismen dominerar i Tornedalen.

Eller formaliserat:

Om A så B

$\mathrm{Om} \mathrm{B}$ så $\mathrm{C}$

$\mathrm{Om} \mathrm{C}$ så D

$\therefore \mathrm{Om} \mathrm{A}$ så D

Klassisk syllogism där A implicerar alla efterföljande premisser.

Men stämmer verkligen denna slutsats? Om man lyssnar till beroendeteoretiker som Frank (1970), Wallerstein (201I) och Amin (1974) så anser de att denna slutsats är riktig beroende på att kapitalismen är ett världssystem som genomsyrar alla delar från ett globalt centrum till de nationella provinserna. Och inom ramen för de nationella provinserna till deras kommunala sektorer via deras regioner. De länder som av olika historiska skäl inte ingår i det kapitalistiska världssystemet står även de i 
ett ekonomiskt beroendeförhållande till kapitalismen som dominerande världssystem. Inte minst genom exproprieringen av det ekonomiska överskott som det beroende landet/regionen/kommunen lyckas frambringa eftersom allt överskott går genom marknaden som domineras av kapitalismen. Detta därför att systemet försöker häva profitkvotens fallande tendens i centrum genom att få ut en högre mervärdeskvot i provinserna. Därigenom frambringas en kontinuerlig underutveckling av dessa länder/regioners/kommuners framtida tillväxt. Detta beror på det kapitalistiska världssystemets struktur av ett centrum som exploaterar sina satellitstater/-regioner/-kommuner som är direkt eller indirekt beroende av kapitalismen som världssystem. I och med denna dominans överförs också kapitalismens inneboende motsättning mellan arbete och kapital till satelliterna, vilket gör att satelliterna utvecklar en kapitalistisk samhällsordning med dess motsättningar. Slutsatsen blir att kapitalismen är allestädes närvarande.

Den här typen av logik, där systemets delar förklaras i sitt upphov och till sitt funktionssätt genom systemets helhet, är inget annat än renodlad historicism (Nordin 198I). Det vill säga, varje samhälles historia är determinerad av någon yttre, oberoende och opersonlig kraft, som likt en naturlag verkar över människans viljeakt. Historien ses som styrande över vars och ens viljeakt genom en överordnad teleologisk princip vars syfte är att förverkliga ett slutmål av endera ett immateriellt slag (till exempel Guds enhetliggörande) eller materiellt slag (till exempel kommunism).

Den historicistiska logiken leder, minst sagt, till en tesdrivande argumentationsform där all empiri passas in i resonemanget, vars syfte är att bekräfta tesens giltighet. Det rör sig om naiv realism där empirin aldrig kan ses som falsifierande (Popper 2002). Det är helt enkelt ingen empirisk prövning som sker. Det är i stället en åsikt som drivs.

I denna artikel kommer jag dock att företa en empirisk prövning av frågan "När kom kapitalismen till Tornedalen?” Det kan tyckas vara en retorisk fråga, men det är inte riktigt så jag vill att du, kära läsare, skall uppfatta den. Jag ser den som en upplysande fråga: Kom verkligen kapitalismen till Tornedalen? Och om den nu gjorde det, när kom den? Sedan ligger det förstås i sakens natur att fråga sig: Vad betydde kapitalismens inträde i Tornedalen för Tornedalens del? 
För att vi ska kunna få svar på alla dessa frågor måste vi få en mer fyllig bakgrund om när i så fall Sverige blev kapitalistiskt (vi måste ha ett referensvärde), vad som i begreppsligt avseende menas med kapitalism och vad det är för typ av källor jag har använt mig av i denna artikel.

\section{Bakgrund}

$\mathrm{Vi}$ vet genom den samlade forskningen inom ekonomisk historia att Sverige i stort genomgick en betydande omvandling från bondesamhälle grundat på självhushållningsekonomi till kapitalism grundad på penning- och marknadsekonomi perioden I800-I930. Det var en omvandling som ledde Sverige från ett av de fattigaste till ett av de rikaste länderna i Europa på I20 år av välfärdsökning och generell jämlikhet mellan klasserna (Bergh 2008).

$\mathrm{Vi}$ vet också att det var i grund och botten samma faktorer som drev hela Sverige framåt i tillväxthänseende i det att mekaniseringen samt organiserandet av ägorättsförhållandena inom jordbruket drev produktiviteten framåt. Man fick ut mer produkter av varje nedlagd arbetstimme. Men i huvudsak var jordbruksproduktionen inriktad mot en hemmamarknad som var för liten för att ge någon utbredd välfärd. Industrialiseringen, framför allt exportindustrin, bidrog till en betydande tillväxt och rationalisering av arbetskraft och konsumtion. Det gav genom sina ökade lönespridningar helt nya och andra förutsättningar för industrin att rationalisera sin produktion, vilket gav ytterligare välfärd i slutändan. Sverige blev allt rikare och tack vare den förda ekonomiska politiken dessutom alltmer jämlikt i fråga om resursfördelning mellan klasserna (Bergh 2008; Schön 2007).

Men frågan är: Skedde denna utveckling mot kapitalism ungefär samtidigt i hela Sverige? Eller fanns det faktorer som gjorde att utvecklingen mot kapitalism skedde regionvis och inte samtidigt i hela landet?

Mig veterligen har inte denna fråga utretts mer ingående i den samhällsvetenskapliga litteraturen. Det tycker jag är trist, därför är mitt syfte att utreda den mer ingående för Tornedalens del. Skälet till detta är i huvudsak kulturpolitiskt, att belysa Tornedalens ekonomisk-politiska betydelse eftersom ingen annan gjort det. 


\section{Källor}

Min utredning baserar sig på sekundärkällor (offentlig statistik och offentliga utredningar) och byhistorisk litteratur om i huvudsak sju byar i övre Tornedalen: Tärendö (Alalehto 200I), Junosuando (Från Junaswa till Junosuando 2000), Korpilombolo (Dahlgren 1984; Ridbäck 20I5a), Kaunisvaara (Kaunisvaara I800-2000 200I), Narken (Ridbäck 20I5b), Männikkö-Vaenvaara (Olofsson \& Greiff 20ıо) och Vittangi (Hanno 1977), om tidsperioden från år I80o till i dag och mer ingående perioden I850-I970.

Fördelen med den här typen av skrifter är att de följer källorna mycket nära den by som de handlar om. Det finns inga svepande förklaringar eller beskrivningar utgående från någon mystisk utomstående kraft eller rörelse där varje enskild by placeras in i en grovskalig historicistisk karta utan att ta hänsyn till alla de små detaljer som kännetecknar just denna by. Källorna rörande byn Tärendö behandlar Tärendö i första hand och tar sin utgångspunkt i Tärendö, även när byns utvecklingsmönster jämförs mot en generell tendens för regionen i övrigt, till exempel arbetsmarknadsutvecklingen (Alalehto 200I). Det är en klar fördel eftersom data i byhistorierna huvudsakligen är primärdata (intervjuer med bybor, nedtecknade berättelser eller anteckningar av bybor, rapporter om byns moraliska tillstånd i samband med till exempel biskopsvisitationer eller sociala tillstånd i samband med att journalister besökt byn och så vidare) och inte bearbetad sekundärdata för andra aggregerande syften. Det ger högre reliabilitet, men tyvärr inte alltid den högsta reliabiliteten eftersom skribenterna bakom de enskilda byhistorikerna kan skifta i såväl innehållslig precision som vilken bild de vill ge av byns historia.

\section{Kapitalismen i Sverige}

En gängse definition av kapitalism är ett ekonomiskt system där produktionsmedlen (arbetsföremål, arbetsmedel och arbetskraft) står under privat äganderätt och där produktionsprocessen regleras genom marknadskrafter (konkurrens och monopoliseringssträvanden). Staten eller andra kooperativa förvaltare har inget eller mycket begränsat inflytande över produktionsmedlen. Detta ekonomiska system är expansivt till sin 
natur. Den kräver en ständig tillförsel av resurser och produktion för att fungera, vilket gör att flera andra institutioner såsom politik (demokrati, partier, fackföreningar etc.) samt rättsordning (privat äganderätt, privat rätt att producera och bedriva handel samt avsaknad av statliga privilegier) är underordnade marknaden (Ingham 2013).

Till denna grundläggande definition kan vi tillföra aspekter som att huvuddelen av befolkningens vardagsbehov ska täckas av varor och tjänster från privata företag; att företagen ska styras av långsiktig lönsamhet baserad på systematisk bokföring samt att arbetsmarknaden skall vara inriktad mot lönearbete och vara helt fri, det vill säga bestå av fria individer som inte likt slavar ägs av någon eller är livegna (Weber 1986). Det är med andra ord en mängd kriterier som måste uppfyllas för att vi ska kunna tala om ifall ett land, en region eller ett län är kapitalistiskt eller inte.

Hur som helst, när inträdde detta ekonomiska system i Sverige? Det går inte att säga exakt eftersom kapitalismen inte införs vid en viss tidpunkt. Kapitalismen är inte en enskild händelse utan en process av händelser som kommer i en viss ordning och i en viss kvantitet för att ge näring att återupprepa händelseordningen men då till en högre kvalitetsordning. Det sker i form av en intervenering i produktionsprocessen, där produktionsmedlen underordnas (subsumeras) under kapitalets generella ackumulation (Marx 2013). Generellt talar man om perioden från I80o till I930, i det att en mer sammansatt marknad för jordbruksprodukter nationellt och regionalt ökade (Schön 2007). I takt med skiftesreformer inom jordbruket, inte minst övergången från tegskifte till laga skifte, kom en mer koncentrerad jordbruksodling till stånd som gav större avkastning för varje hushåll. Bland annat dubblerades ytan av odlad jord i och med skiftesreformerna och därmed överfördes ett överskott av varor till marknaden (Bergh 2008). Det drev på en kapitaltillväxt som gick till investeringar i jordbruksteknik och infrastruktur, vilket drev på arbetsrationaliseringar så att mängder av arbetskraft friställdes och flyttade in till städerna vilket i sin tur bidrog till att marknaden koncentrerades till städerna.

Tids nog inleddes även en industriell utveckling, främst inom hantverk, fabriker och manufaktur samt bergshantering. Det var en följd av avregleringar av till exempel skråväsendet och minskade tullrestriktioner, 
men också en kraftig arbetskraftstillströmning. Den årliga tillväxttakten I830-I850 inom olika industriella branscher är betydande, från 2 upp till 9 procent, medan jordbruket inte hade högre tillväxt än I, 5 procent årligen (Schön 2007). Differensen i tillväxttakt och produktion mellan jordbruket och industrin blev därefter allt större mellan I86I och I940, då differensen generellt var 4,5 till 5 procent periodvis mellan sektorerna. Bland annat gav arbetskraftsmigrationen från jordbruk till industri en överflyttningsvinst på I4 procent I87I-I890, I9 procent I89I-I9I5 och hela 25 procent $\mathrm{I} 92 \mathrm{I}-\mathrm{I} 940$ av produktiviteten för landet i sin helhet. Detta av det enkla skälet att människor flyttade från lågproduktiva till högproduktiva sektorer. Man fick ut mer produktivitet av varje nedlagd arbetstimme. Och det var framför allt de exportinriktade sektorerna (sågverk, järn- och stålindustri samt gruvbrytning) som drev denna utveckling framåt (Magnusson 2002). Det var också i den expansiva exportindustrin som produktionsmedlen i huvudsak var underordnade det privata ägandet (inhemskt och utländskt), och produktionen löd under marknadens krafter av pris- och varukonkurrens med lågt eller inget statligt inflytande.

Skillnaden i tillväxttakt mellan lågproduktiva (jordbruk) och högproduktiva sektorer (främst exportindustri) ledde naturligt nog till stora skillnader i reallöneutveckling. Och ju fler arbetare som kom över till de högproduktiva sektorerna, desto mer stärktes konsumtionsindustrin, framför allt verkstadsindustri, textilindustri och livsmedelsindustri (Magnusson 2002; Schön 2007). Det blev kort sagt mer pengar i den inhemska marknaden, vilket gjorde att även dessa marknader blev expansiva och därmed intressanta att subsumera under en kapitalistisk produktionsordning.

Sägas skall också att på det rättsliga området hade Sveriges riksdag redan I864 antagit en näringsfrihetsförordning, som formellt fastslog rätten för varje privatperson att etablera ett kommersiellt inriktat företag. Det hade fram till dess varit förbehållet de privilegierade. Bland annat fick kvinnor rätt att bedriva företag i och med denna förordning. Näringsfrihetsförordningen stadgade den privata äganderätten över produktionsmedlen, näringsidkarnas respekt för kontraktet och ett patentoch märkesskydd (Magnusson 2002).

Därutöver utvecklades parallellt ett fungerande privatägt kreditväsende (banker och finansiella institutioner); en förbättrad infrastruktur 
genom ömsesidigt ägarskap mellan stat, kommuner och privata aktörer av kommunikationer (järnväg, teleförbindelser, vägar, postleder, sjöfartsleder etc.); valutastabilitet (silvermyntfot) samt klara statliga regler som underordnade sig marknadens behov av långsiktiga bedömningar och entreprenöriellt risktagande (Magnusson 2002; Schön 2007).

För att göra en riktigt lång historia riktigt kort kan man säga att Sverige blev i huvudsak kapitalistiskt mellan I890 och 1930. Om man ser till produktionsvolymen i jordbruket, industrin och tjänstesektorn skedde övergången mellan 1900 och I9I0, och ser man till förädlingsvärdena, det vill säga avkastningen per arbetstimme, skedde övergången mellan I890 och I930 (Schön 2007). Men det skall samtidigt sägas att Sverige aldrig har varit helt och hållet kapitalistiskt. Det har alltid funnits, och finns, betydande inslag av statligt och demokratiskt inflytande över produktionsprocessen som reglerats av politiska strävanden. Före I850 motiverades statens inflytande av militära skäl och därefter av civila skäl (arbetsmarknadsreformer, näringspolitiska reformer och så vidare) (Magnusson 2002).

\section{Kapitalismen i Tornedalen}

Att Sverige i huvudsak blev kapitalistiskt mellan I890 och 1930 betyder inte att Tornedalen därmed blev det. Om det vittnar om inte annat byhistoriken när man jämför den med den föregivna definitionen av kapitalism.

\section{Jordbruket}

Den svenska delen av övre Tornedalen var under hela I8oo-talet och fram till ı9ıо i princip helt och hållet ett privatägt jordbrukssamhälle. Mängden bönder, nybyggare, kronotorpare och arrendatorer, och inte minst de till bondehushållet tillhörande kategorierna pigor, drängar, jordbruksarbetare och inhysingar, översteg vida alla industriella (timmermän, arbetare, skogsarbetare och hantverkare) och kommunala yrkeskategorier (barnmorskor, lärare etc.). Förhållandet var att minst nio av tio yrkesarbetande tillhörde den agrara sektorn (Alalehto 200I).

Det betyder att det privata ägandet var ordentligt utbrett inom det tornedalska jordbruket. Den tornedalska bonden ägde rätten över sina 
produktionsmedel i det att han och hans familj utgjorde arbetskraften, stod för arbetsmedlen (enklare handverktyg, möjligtvis en och annan häst) samt ägde arbetsföremålet (åkerareal, några kor, några får och några renar). Det fanns förvisso marknader för varuförsäljning av gårdens produkter, men de var begränsade till vissa platser och tider. Det mesta av gårdens produktion gick till gårdens självhushåll. Korna stod för mjölk, smör, filmjölk och kött. Fåren stod för ull, skinn och kött. En viss renskötsel förekom, vilket gav kött. Jordbruket i övrigt gav säd och potatis. Fisk hämtades från närliggande sjöar och bäckar eller älven. En del produkter, till exempel vadmalsstövlar och tjärtunnor, gick till marknaden för införskaffandet av pengar, varmed bonden kunde handla varor som han själv inte kunde tillverka (Alalehto 200I; Kaunisvaara I800-2000 200I).

Något bönder hade råd med var pigor och drängar. De var formellt underställda bondens privata äganderätt över arbetskraften, men i princip fick de själva arbeta in sin lön in natura (kläder, ull, mat och logi). Det mervärde som följde av deras arbetsinsats är oklart och diffust. Det mesta talar för att det rörde sig om en sorts livegenskap där pengar sällan eller aldrig utbetalades, utan pigorna och drängarna fick sin lön in natura efter vad bonden tyckte sig ha råd med efter att ha dragit av för omsorgen. Det var en lönesättning som var svår att realisera i pengar. Inhysingar som ingick i bondehushållet var för det mesta en närstående släkting som av någon orsak inte kunde ta hand om sig själv. Det är oklart i vilken mån inhysingar utgjorde arbetskraft av något slag eller belastade hushållets resurser. Det fanns säkerligen olika varianter av insatser som inhysingarna utförde, beroende på deras fysiska status och det enskilda hushållets behov av arbetskraft, men någon fri arbetskraft var det aldrig frågan om (Alalehto 200I; Kaunisvaara I800-2000 200I).

En viss skattesats kunde hämtas ur ett någorlunda självbärande bondehushåll. Dock inte nybyggen, som var skattebefriade i tio år. Skatten gick till kommunal fattigvård, skola, rotesoldater, vägbyggen och kyrkan (byggnadsuppförande, offentliga tjänster, underhåll, bränsle etc.) och till inköp av till exempel spannmål vid missväxtår som satte enskilda nödställda under betungande lån till kommunen. Genom skattesystemet fick kommunen inflytande över byggverksamhet och vägbyggen, och kunde dessutom genom skatteutjämningsbidrag och statliga lån bidra till bön- 
dernas "hjälp till självhjälp". Det gjorde sammantaget att kommunen blev en inflytelserik aktör över de privatägande bönderna. Förvisso kontrollerade inte kommunen direkt ägarskapet över produktionsmedlen, men den påverkade villkoren för detta ägarskap.

Långsiktig lönsamhet med systematisk bokföring som grund för ett instrumentellt företagande (Weber 1986) är så långt borta man kan komma när det gäller den tornedalska bonden under denna period. Jordbruket var småskaligt och handlade om att hålla näsan ovan vattenytan i syfte att klara livhanken dag för dag. Det pågick en ständig kamp för att få intäkter och utgifter att gå ihop. Det fanns inga förutsättningar att bygga upp ett eget kapital eftersom det helt enkelt inte fanns någon expansiv marknad $\mathrm{i}$ något avseende $\mathrm{i}$ övre Tornedalen vid denna tid. När det gällde arbetsmarknaden var den fri för de offentliga tjänsterna (lärare, präst, barnmorska). Men den arbetsmarknaden var inte underställd privata aktörer. För pigor, drängar och inhysingar var den fria arbetsmarknaden ytterst begränsad, för dem rådde snarare livegenskap. En del av jordbruksarbetarna var formellt fria, men det var i realiteten en frihet som villkorades av en begränsad arbetsmarknad i fråga om fria yrken och dessutom begränsades av de privata böndernas snäva kostnadsramar.

Förvisso bidrog övergången till laga skifte under I88o-talet till en viss ökning av jordbruksproduktionen. Det var en omfattande jordbruksreform som berörde hela Sverige. Den innebar att ägorna skulle samlas hos en enskild ägare och koncentreras runt dennes gård. Syftet var att klara upp oklara ägorättsförhållanden och inte minst minska de ineffektiva transportavstånden mellan gård och äng. Skötseln av ägorna skulle kontrakteras och avkastningen skulle öka eftersom transporttiden minskade. För Tärendös del började reformen genomföras under i88o-talet och slutfördes I892 (Alalehto 200I), i Narken inleddes reformen I893 och slutfördes I896 (Ridbäck 20I5b), i Korpilombolo genomfördes reformen I876 (Ridbäck 20I5a), i Junosuando inleddes reformen I88I och slutfördes I885/1887 (Från Junaswa till Junosuando 2000), i Vittangi genomfördes reformen så sent som vid början av 1920-talet (Hanno 1977) och i Männikkö-Vaenvaara slutfördes reformen inte förrän 1947 (Olofsson \& Greiff 20IO, s. 38). 
Redan perioden innan det laga skiftet började genomföras utfördes en rad omfattande kommunala alternativt kooperativa insatser (bönderna gick samman) för att öka avkastningen från jordbruket: sjösänkningar och dikesgrävning för att torrlägga ännu mer areal. Till exempel återvanns drygt 3-4 hektar årligen i snitt per kommun I885-1910 via avvattning (SOS 1938). Strävan att öka avkastningen tog sig också andra uttryck, som att bönderna gick samman i kooperationer eller genom samfällighetsföreningar för att investera i plogar, harvar, slåttermaskiner och gödselspridare. Liknande organisationsformer låg bakom beslut att investera i konstgödsel, kvarnar, mejerier, gemensam avelsverksamhet, förbättrad djurutfodring, gatubelysning etc. (Hanno 1977; Alalehto 200I; Ridbäck 20I5b; Från Junaswa till Junosuando 2000; Kaunisvaara I800-2000 200I).

\section{Skogsbruket}

Perioden 1920-1950 kännetecknades av en betydande ökning av yrken och yrkesarbetande inom skogsbruket. Förhållandet var att det gick i snitt drygt 0,65 yrkesverksamma inom skogsbruket på I,O yrkesverksamma inom jordbruket. I själva verket var tendensen ännu något starkare på grund av att den omfattande hemmansklyvningen gjorde att flertalet bönder (som var fler till antalet än perioden I80o-I9IO) ägde allt mindre jord och tvingades söka biinkomster inom skogsbruket för att klara familjens uppehälle (Alalehto 200I). Med all sannolikhet ägde dock en del av dessa hemmansägare häst och anställdes därför av skogsbolagen som hästkarlar, vilka i sin tur anlitade huggare under sig som de ansvarade för i någon form av förmansställning (Kaunisvaara I800-2000 200I).

Av 2723 skogsarbetare 1934 var 19,6 procent hemmansägare, 26,5 procent söner till hemmansägare, 6,I procent arrendatorer och 6,8 procent söner till arrendatorer (SOS 1938). Övre Tornedalen genomgick därmed ett betydande "bondeoffer" under 1920-, 1930- och 1940-talen, då gårdsägande bönder proletariserades periodvis över året. Det gällde också till stor del småbruksägarna (Alalehto 200I).

I920 fanns det i Övertorneå tingslag 750 brukningsenheter som ägde sammanlagt $5 \mathrm{I} 9$ hektar odlad åkerjord ( 0,7 hektar var), 3II brukningsenheter som ägde sammanlagt I 206 hektar (3,8 hektar var) och is bruk- 
ningsenheter som ägde sammanlagt 226 hektar (II,9 hektar var). I Korpilombolo tingslag vid samma tid ägde 462 brukningsenheter 290 hektar ( $\mathrm{I}, 6$ hektar var) odlad åkerjord mot 59 brukningsenheter som ägde 178 hektar (3 hektar var). Det fanns 776 kor i Korpilombolo I920, det vill säga 0,7 kor per brukningsenhet. I Pajala tingslag ägde vid samma tid 457 brukningsenheter 4Io hektar (I,I hektar var) odlad åkerjord, I28 brukningsenheter 440 hektar ( 3,4 hektar var) och två brukningsenheter 52 hek$\operatorname{tar}(26$ hektar var). Enheterna ägde sammanlagt 249 kor, det vill säga 0,4 kor var (SOS 1923).

Lite över tio år senare, 1932, hade situationen förbättrats något i Pajala kommun. Det fanns 427 jordbruk men bara 25 av dem hade minst fem hektar, minst 250 av dem hade två hektar eller mindre. Av samtliga bönder var det endast 39 som hade fler än fem kor. Flera av bönderna i 1920 års statistik hade med andra ord upphört med sitt jordbruk och tagit anställning inom skogsbruket eller inom gruvbrytningen i Malmfälten eller emigrerat till USA. En liknande utveckling skedde 1935-1945 i Vittangi kommun, där det fanns sammanlagt högst Ioo hästar och 300 kor på IOO gårdar. En officiell uppskattning vid denna tid var att en bonde för att kunna försörja sig på sitt jordbruk måste ha minst åtta hektar odlad jord samt minst sju kor och en kviga förutom häst och smådjur. Det var ytterst få bönder som uppnådde detta vid övre Tornedalen vid denna tid (Hanno 1977; Lundmark 1985). Som läsaren förstår fanns det inga förutsättningar att klara livsuppehället eller på något sätt utveckla en expansiv kapitalmarknad baserad på jordbruk. Den självägande bonden måste helt enkelt ha en annan biinkomst.

Det var inte bara bönderna och småbruksägarna som genomgick denna proletarisering. Till följd av den avvittring som staten genomförde med början på I60o-talet, och som för Tornedalens del inte avslutades förrän vid 1900-talets början, kom en hel del kronotorpare, skogstorpare och lägenhetsinnehavare att uppstå som socioekonomiska kategorier. Utgångspunkten var att staten ville överföra sina eftersatta skogsarealer, som inte direkt lämpade sig för jordbruk, till självägande bönder som ett led i skogsskötseln och för att eventuellt stärka böndernas ekonomi. Men intresset för avvittringen varierade betänkligt och det var inte förrän skogsbolagen visade intresse på I880-I920-talet, när 
träprodukter var en betydande svensk exportvara, som skogen blev av primärt ekonomiskt intresse för staten och för bolag som $A B$ Bergman Hummel \& Co, Baltiska Trävaruaktiebolaget, Nordiska Trävaru AB och Kalix Trävaruaktiebolag.

Problemet var bara att skogsbolagen i Tornedalen avverkade skogen mycket hårt utan att ta något ansvar för dess skötsel. Det ledde till att Skogsstyrelsen I888 uttryckte uppfattningen att det skulle bli brist på skog. Avverkningskontrakten begränsades I889 till 20 år, vilket fick till följd att de privata skogsbolagen började köpa upp hemman. Trävarubolaget Bergman Hummel \& Co ägde 176 hemman, över tre miljoner träd, i bara Korpilombolo kommun I895. Bolaget ägde vid samma tid stora mängder hemman och träd i Rödupp, Tärendö och Gyljens revir, allt som allt till ett värde av 240,4 miljoner kronor i 2010 års penningvärde (Ridbäck 20I5b, 20I5a). Det kan tyckas vara stora siffror, men i själva verket ägde trävarubolagen enligt Dahlgren (1984) en förhållandevis liten del av skogsmarken i Korpilombolo. Det var staten som ägde de stora volymerna ı9ı0, och hemmansägarna (så kallade enskilda skogsägare) ägde cirka 25 procent av skogen i Korpilombolo.

I hela övre Tornedalen ägde staten vid mitten av 1930-talet 49, I procent av skogen, enskilda skogsägare 47 procent och skogsbolagen inte mer än 3,9 procent (SOS 1938). Staten kvarstod som ägare av en betydande mängd skog, som måste förvaltas och inte minst skötas på sådant sätt att den blev lönsam. Lösningen blev till en början att upprätta kronotorp/skogstorp/lägenheter/kolonat (nyckelfärdiga hus) till obemedlade och mindre bemedlade personer som gjort sig kända för sin idoghet, arbetsamhet och hederlighet. De fick överta en bit mark för att under kontrakterade former driva ett mindre självhushållande jordbruk med visst avkastningskrav och säsongsvis ta skogsarbete när skogsbolagen sökte arbetskraft. På detta sätt kunde mer jord odlas, skogen runt torpet/ lägenheten sköttes för statens intressen och Skogsstyrelsen och de privata skogsbolagen hade tillgång till en fast arbetarstam när skogsavverkningarna genomfördes (Ridbäck 2015a, 20I5b). I934 bestod Tornedalens skogsarbetarstam till 23,6 procent av kronotorpare och 17,4 procent av ospecificerade lönearbetare (SOS I938). I9I2 övergick en del av kronotorparens kontraktsskyldighet som fri arbetskraft inom skogsbruket till det 
statliga affärsdrivande Domänverket. Domänverket ombildades 1942 till Assi skogsindustrier, och därefter 1999 till Sveaskog AB.

Kronotorparen/skogstorparen/lägenhetsinnehavaren hade en socioekonomisk ställning som var en märklig mix av fri arbetskraft och statlig livegenskap. Kontraktet för kronotorpet omfattade en rad skyldigheter och avkastningskrav, dock aldrig så att det fick konkurrera med statens behov av skogsskötsel och skogsarbete. Kronotorparen var formellt en fri företagare, men någon ekonomisk långsiktighet i sitt självhushåll kunde han inte räkna med. Den ekonomiska långsiktigheten bestod främst i hans roll som arbetskraft åt Skogsstyrelsen, vilken täckte stora delar av hans vardagsbehov av varor och tjänster (Ridbäck 20I5b; Dahlgren 1984).

Torparna försvann successivt under 1940-talet. Under 1950-talet försvann arrendatorer och småbruksägare till följd av för låg avkastning och strukturrationaliseringen av den svenska arbetsmarknaden (överflyttningen av arbetskraft från lågproduktiva till högproduktiva sektorer) (Alalehto 200I; Öström I980).

Den försörjningsmix av jordbrukande och skogsbrukande som gällde för kronotorparen/skogstorparen/lägenhetsinnehavaren var också påtaglig bland de jordbruksarbetare som var beroende av skogsbruket för sitt uppehälle. Andelen jordbruksarbetare var som störst 1940 för att sedan stadigt minska till noll 1970 (Alalehto 200I). Deras ställning som fri arbetskraft var som tidigare tvetydig, men oavsett det ökade andelen fria arbeten på arbetsmarknaden från I950 (på arbetarsidan: skogsarbetare, flottare, sågverksarbetare och chaufförer; på tjänstemannasidan: skogsfaktor, virkesmätare och skogsförman) fram till 1970 parallellt med att industriellt inriktade företagare (hantverkare, åkare, sågverks-/snickerioch verkstadsägare) ökade i motsvarande mån. I takt med avverkningarna ökade transportbehovet, vilket ger upphov till åkerier och chaufförer. Det skedde också en ökning av så kallade offentliga tjänster och diverse biträden på över 400 procent från 1920 till 1970, samtidigt som pigorna, drängarna och tjänarinnorna försvann helt under 1930-talet (Alalehto 200I; Från Junaswa till Junosuando 2000; Ridbäck 2015b).

När det gäller perioden 1920-1970 var övre Tornedalen överlag ett jordbrukssamhälle fram till I950. Tornedalens befolkning var 1930 till 69,7 procent verksamma i jordbruket med binäringar ( 54,5 procent jord- 
bruk och boskapsskötsel och I4,9 procent skogsbruk), I3,3 procent i industri och hantverk, 6,8 procent i handel och 3,I procent i offentlig tjänst (SOS I938). Fram till I950 hade dock försörjningsmönstret omvandlats så att Tornedalens befolkning i huvudsak kombinerade skogs- och jordbruk, med skogsbruket som dominerande inkomstkälla (SOU I958:22, Tornedalsutredningen). Till exempel kombinerade 72,5 procent av Junosuandos befolkning skogs- och jordbruk som inkomstkälla, en lika stor andel i Tärendö kommun, i Korpilombolo 65,7 procent, Pajala 62,6 procent och Övertorneå 49,8 procent. Det skedde även en överflyttning till det som Tornedalsutredningen kallar stadsnäringar (handel, industri, offentliga tjänster etc.), som under samma period sysselsatte mellan 26 och 3I procent av befolkningen i dessa kommuner (ibid.).

I takt med att skogsbruket blev alltmer dominerande under 1950talet slutade allt fler av Junosuandos bönder med djurhållningen och gick över till enbart skogsarbete (Från Junaswa till Junosuando 2000). Det möjliggjordes av att skogsbolagen började anställa helårsvis i stället för säsongsvis (Mäkipiha 2007). Det var en utveckling som gällde i lika mån för Korpilombolo (Dahlgren 1984) och för Tärendö, där förskjutningen var påtaglig: från 33 procent sysselsatta i jordbrukssektorn I960 till 44 procent i industriell sektor (skogsbruk, transport och hantverk) och 23 procent i offentliga tjänster eller statligt/kommunalt understödda arbeten (Alalehto 20or). Parallellt med denna utveckling skedde en viss utbyggnad av bank- och kredittjänster under tidigt 1960-tal, och tillgången till belåning och kontanta medel för konsumtion underlättades i och med att bankkontor förlades till exempelvis Junosuando (Från Junaswa till Junosuando 2000).

Det kapitalistiska inslaget under denna period utgjordes otvetydigt av skogsbolagen, framför allt statliga Assi men också privatägda skogsbolag, som ägde i mediantal 44,3 procent av skogsmarken i Övertorneå, Korpilombolo, Tärendö, Pajala och Junosuando 1957. Resten var så kallade bondeskogar, allmänningar och kyrkoskog (SOU 1958:22). Trots att skogsbolagen inte ägde merparten av skogen var de en inflytelserik aktör som ägde produktionsmedlen, täckte vardagsbehovet av varor och tjänster hos skogsarbetarna, agerade företagsekonomiskt långsiktigt baserat på systematisk bokföring och rekryterade arbetskraft från en fri arbetsmark- 
nad. Till detta kunde mindre egenföretagande, det vill säga småborgerlighet, kopplas i form av åkerier, snickerier, verkstäder och hantverkare som verkade på marknadsmässig basis. Samtidigt ska det sägas att åkerierna inte bara utförde timmertransporter utan också person- och godstransporter kontrakterade av kommunerna (Ridbäck 20I5b). Det var en expansiv och växande marknad.

Det välfärdsstatliga eller kommunala inflytandet var i princip helt frånvarande när det gällde dessa industriella sektorer vid denna tid. Välfärdsstatens insatser riktades i stället till den växande arbetskraftsarmé som blev följden av skogsbolagens ständiga rationaliseringar av produktionsprocessen (bandtraktorer med tre gånger högre lastkapacitet än hästar, mekaniska lyftanordningar för timret, motorsågens inträde och så vidare) (Alalehto 200I; Från Junaswa till Junosuando 2000; Dahlgren 1984). Andelen arbetskraft, variabelt kapital, minskade i relation till andelen effektivare arbetsmedel, konstant kapital. Konsekvensen blev att produktiviteten per nedlagd arbetstimme ständigt steg och behovet av arbetskraft minskade, vilket ledde till omfattande arbetslöshet med åtföljande arbetslöshetsunderstöd (ekonomiska bidrag, arbetsmarknadsutbildning, bidragsunderstödda kommunala arbetsprojekt etc.). Eftersom jordbruket vid samma tid genomgått arbetsrationaliseringar som varit nödvändiga för att följa prisutvecklingen på marknaden, och i sin helhet var icke-expansivt på grund av brist på tillräckligt stora jordbruk, brist på fasta anläggningar för förvaring och vidareförädling samt brist på rationella driftsformer, så kunde inte jordbruket svälja mängden friställda arbetare från skogsbruket (SOU 1958:22; SOU 1960:37; Kaunisvaara $1800-2000$ 200I).

Sammantaget gjorde de två Tornedalsutredningarna bedömningen att Is hektars åkerareal var den absolut lägsta gränsen för att försörja en jordbrukande familj. I annat fall måste jordbruksarbetet kompletteras med annan inkomst eller läggas ned. 1956 hade endast tio jordbruk av totalt $284 \mathrm{I}$ i övre Tornedalen en bärkraft överstigande 15 hektars åkerareal. Den absoluta majoriteten hade under 5 hektar. Det ledde till en betydande befolkningsminskning när människor tvingades flytta till olika delar av Sveriges högproduktiva sektorer. 1957 var nettoförlusten (skillnaden mellan in- och utflyttning) 4900 personer till övriga 
Norrbotten och 4 Ioo personer till övriga Sverige. Och de jordbrukare som trots allt stannade kvar med 5-I5 hektar åkerareal tvingades bli mer eller mindre beroende av bidrag från skogsmedelsfonder, hushållningssällskap och staten (SOU 1958:22; SOU 1960:37).

Att det kapitalistiska inslaget växte under perioden 1920-1970 betydde långt ifrån att alla delar av näringslivet därmed var satta under kapitalets subsumtionsprocess. Jordbruksarbetarnas ställning som fri arbetskraft var fortfarande tvetydig och ökningen av de offentliga tjänsterna under perioden hängde samman med att de statliga, kommunala och kooperativa inslagen (till exempel Röda korsets insatser) ökade i form av fler lärare, vaktmästare, provinsialläkare, sjukskötare, telefonbiträden, postpersonal, omvårdnadspersonal etc. (Hanno I977; Minnen och episoder från sjukstugan och ålderdomshemmet $i$ Övertorneå 1995). Till detta kom alla vägarbeten (1930- och 1940-tal) samt linjearbeten för att dra och underhålla kraftledningarna till övre Tornedalen från 1950-talet till åtminstone 1970 (Alalehto 200I; Öström 1980). Alla dessa tjänster och verksamheter stod under statligt eller kommunalt ekonomiskt inflytande. De utgjorde sammantaget kommunernas infrastruktur och var en förutsättning för privatkapitalistisk tillväxt, inte tvärtom. Det vill säga det kapitalistiska inslaget i övre Tornedalen betingades av vilka insatser stat och kommun var beredda att göra för att skapa de reproduktiva förutsättningarna för en kapitalistisk produktionsprocess.

Staten och kommunen utövade inflytande även över den industriella sektorn, via det statliga Domänverket (senare Assi), som inte var enbart kapitalistiskt orienterade i sitt skogsbruk 1945-1965 i övre Tornedalen. Det vill säga de anpassade inte helt och hållet sin verksamhets storlek till marknadens mekanismer (om tillgången av en vara ökar utan att efterfrågan ökar så pressas priset nedåt, och vice versa).

Försäljningen av virke (bjälkar, sågat timmer, vindfälld skog, stubb och så vidare) genererade 1920 för Tärendös del $210580 \mathrm{kr}$ och för Korpilombolos del $355466 \mathrm{kr}$, medan utgifterna låg på blygsamma $48306 \mathrm{kr}$ respektive $98249 \mathrm{kr}$. Det är ingen tvekan om att här var bruttoavkastningen mycket stor för Domänverkets del.

Men bruttoavkastningen började minska 1925-1940 och blev 1945I965 avsevärt sämre, det blev till och med en förlustverksamhet på grund 
av investeringar i vägar, kojor, utbildning, avvattning, uppförande av anläggningar av olika slag och så vidare. I Tärendö revir 1945 avverkades I09 382 kubikmeter virke, vilket inbringade $904073 \mathrm{kr}$ i inkomst men medförde 989543 kr i utgifter; i Korpilombolo revir var volymen 8I 723 kubikmeter, inkomsterna I 077585 kr och utgifterna I 170 090 kr. Liknande resultat uppvisade Korpilombolo revir 1950 och båda reviren 1960 och 1965, samtidigt som avverkningarna i kubikmeter ökade något över perioden.

Förklaringen till att Domänverket/Assi drev denna omfattande förlustbringande verksamhet inom ramen för en marknadsekonomi var att de är ett affärsdrivande verk under regeringens kontroll. Regeringen kan ställa upp målsättningar för verket som inte är strikt marknadsorienterade. Skogsbruket i Tärendö och Korpilombolo revir skulle ha varit lönsamt om inkomsterna och utgifterna bara höll sig till avverkningen. men eftersom regeringen har ansvar för statens välbefinnande och staten har ansvar för skogstillgångarna så blir avverkningsinkomsterna knutna till skogsskötsel i bred mening, det vill säga fröplantering, slyrensning, avvattning, personalutbildning och löner till personal som inte direkt ägnar sig åt avverkning, en betydande utgiftspost.

Verksamheten blev samtidigt ett sätt för regeringen att hålla arbetsmarknaden under armarna i övre Tornedalen. Den socialdemokratiska regeringen hade 1948 i och med introduktionen av Arbetsmarknadsstyrelsen (AMS) formulerat en avsikt att upprätthålla hög sysselsättning med hjälp av lokaliseringsstöd, offentliga arbeten, subventioner av olika slag, arbetskraftsutbildning etc. i utsatta regioner (Hansen, Hultberg \& Söderlund 1976). 1960 års Tornedalsutredning gjorde en bedömning av vilka möjligheter det fanns att etablera en större industriell verksamhet $\mathrm{i}$ övre Tornedalen som skulle kunna gå med vinst, och de konstaterade att det fanns åtminstone fem större hinder: För det första stora svårigheter att finna tillräcklig skicklig företags- och arbetsledning som ville etablera sig i Tornedalen. För det andra stor brist på tillräckligt skicklig arbetskraft som ville etablera sig i Tornedalen, i annat fall måste den inhemska arbetskraften utbildas vilket medförde kostnader. För det tredje högre arbetslöner i Tornedalen än på flertalet andra orter i Sverige. För det färde högre investerings- och driftskostnader för anläggningar på grund 
av klimatet. För det femte högre kostnader för försäljning och avsättning på andra marknader (SOU 1960:37).

Utredningens åtgärdsförslag hade en typisk prokapitalistisk inriktning: en fri arbetsmarknad på både tjänstemanna- och arbetarsidan, en utbildningsnivå som möjliggjorde en rationell och kostnadseffektiv drift, en fond för främjande av företagandets utveckling samt billigare transportlösningar för att sälja varor och tjänster på marknaden. Vi vet så här långt att inget av detta har lyckats för Tornedalens del. Inte ens vid etablerandet av gruvbolaget Northland Resources runt 20Io lyckades man komma tillrätta med de problem som redan 1960 års Tornedalsutredning hade funnit.

I stället gick inriktningen av produktionsordningen i mångt och mycket i motsatt riktning för övre Tornedalen: statliga och kommunala tjänster ökade på bekostnad av privatiserade industriella tjänster.

\section{Offentliga tjänster}

Vid ingången till 1980-talet tilltog nedgången i alla sektorer i Tornedalen. Mest märkbart var det inom jordbrukssektorn: kvar blev endast två eller tre bönder per Tornedalsby, om ens någon (Från Junaswa till Junosuando 2000). Antalet jordbrukande yrkeskategorier sjönk väsentligt, och vid slutet av 1990-talet var jordbruket helt nedlagt i Kaunisvaara (Kaunisvaara I800-2000 200I). Även skogsbruket och den redan småskaliga industristrukturen påverkades. Inom skogsbruket i Norrbottens och Västerbottens län minskade antalet årsarbetskrafter från II2 till 78 (lite drygt 30 procent) på endast tio år, 1970-1980 (SKS 1982). Och nedgången fortsatte (Från Junaswa till Junosuando 2000, s. I04, se även Olofsson \& Greiff 20I0, s. I27 samt Dahlgren 1984, s. 88-97 och Kaunisvaara I800-2000 200I, s. 49):

Idag [slutet av 1990-talet] gör 3 skördare, 3 skotare och 4 man per skördeenhet, totalt med servicefolket I5 man, samma arbete som tidigare [1950-talet] krävde 50 till 60 man.

Det är egentligen bara de offentliga tjänsterna inom sjukvård och skola, och på senare tid inom omsorg och barnomsorg, som inte har minskat lika mycket, och därmed har de ökat i förhållande till jordbruket 
och industrin. Men sedan 1990-talet har det inom denna sektor skett betydande arbetsrationaliseringar med sammanslagningar av enheter på grund av bristande befolkningsunderlag (Frain Junaswa till Junosuando 2000; Minnen och episoder frän sjukstugan och ålderdomshemmet i Övertorneå 1995). Skälet står att finna i en omfattande utflyttning av arbetskraft till regioner med arbetskraftsbrist.

Statistiken talar sitt tydliga språk om man tittar på hur förvärvsarbetet utvecklas perioden 1985-20IO. Mellan 1985 och 1995 sjönk jordbruket i förvärvsfrekvens från 20 procent i Pajala och Övertorneå till endast 8 procent i Pajala och 7 procent i Övertorneå 1995. Industrin, dit skogsbruk räknas, hade i Pajala och Övertorneå en förvärvsfrekvens på 20 procent 1985 och sjönk endast marginellt till I9 procent 1995. Däremot ökade servicenäringen (framför allt offentliga tjänster men också en del privata) från 50 procent i Pajala och 60 procent i Övertorneå 1985 till 73 respektive 74 procent 1995 . Verksamheterna var för Pajalas del till 46 procent och för Övertorneås del till 53 procent i privat ägo 1995. Denna skillnad i ägarkontrollen mellan de två kommunerna stod sig 2005, då 52 procent av förvärvsarbetet stod under offentlig regi i Pajala, medan det omvända gällde för Övertorneå, där 52 procent av förvärvsarbetet stod under privat regi. Det kom dock att förändras radikalt på bara fem år, då etablerandet av det privatägda norsk-kanadensiska gruvbolaget Northland Resources i Pajala höjde andelen förvärvsarbete i privat regi till 56 procent medan andelen förvärvsarbete i offentlig regi i Övertorneå ökade till 54 procent.

\section{Diskussion}

När kom då kapitalismen till Tornedalen? Svaret är inte tvärenkelt. Det vi kan konstatera är att kapitalistiska yttringar visade sig redan under I88o-talet i form av de privata skogsbolagen i bland annat Korpilombolo revir. Men dessa yttringar var långt ifrån en dominerande produktionsordning för regionen som sådan.

I själva verket var jordbruket med självhushållande bönder helt dominerande under I800-talet fram till egentligen 1950. Dessa bönder ägde förvisso produktionsmedlen privat, vilket är ett viktigt kriterium 
för kapitalism. Men man kan inte med bästa vilja säga att de var kapitalister. Bönderna strävade inte efter att rationalisera driften (genom att klara ut ägorättsförhållanden, minska transportavstånden, höja mekaniseringsgraden, minska arbetskraftsberoendet etc.) därför att de i grund och botten var inriktade på att klara hushållets uppehälle. Produktionen (av kött, skinn, spannmål etc.) syftade inte till kapitaltillväxt, det vill säga att öka avkastningen så att överskottet kan investeras. De försök som gjordes för att öka produktavkastningen från jordbruket (liksom skogsbruket) skedde på initiativ av riksdagen, genom avvittringen eller det laga skiftet. Det var statens förvaltningsansvar som drev de självhushållande bönderna att bli mer marknadsorienterade och få högre avkastning. De tornedalska bönderna "protesterade" mot dessa åtgärder genom till exempel hemmansklyvning, som ledde till allt mindre och helt olönsamma åkerarealer. Och det var detta som gjorde att jordbruket aldrig blev kapitalistiskt dominerande i Tornedalen.

I varje fall var det någonstans runt 1920-1930 som konsekvenserna av hemmansklyvningen och sämjedelningen ${ }^{\mathrm{I}}$ av skogsmarken till allt mindre skogslotter började bli materiellt kännbar för de kvarstående hemmansägarna och deras söner. De måste komplettera sina inkomster med biinkomster från skogsbruket. För någon industri i övrig mening (gruvbrytning, hantverk, snickeri, byggnad, verkstad etc.) fanns egentligen inte. Den industri som fanns var i själva verket mer betingad av skogsbrukets utbredning än av sin egen innovativa kraft.

Med utgångspunkt i detta kan vi konstatera att nedgången av ett icke-expansivt jordbruk och därmed friställandet av arbetskraft på en arbetsmarknad för skogsbruket kan synas vara en indikation på att kapitalismen började dominera i Tornedalen. Liksom att de privata skogsbolagen arrenderade och köpte upp skog och blev en allt större skogsägare. Om dessa villkor vore tillräckliga för att signalera kapitalismens inträde så kom kapitalismen till Tornedalen under 1920-talet. Men detta är inte fallet, eftersom de privata skogsbolagen ägde högst 5 procent i snitt av skogstillgångarna i övre Tornedalen och arbetskraften bara var säsongsvis fri. Den främsta skogsägaren var staten via Domänverket, därefter

I. Två eller fler ägare delar upp fastigheten mellan sig utan direkt hänsynstagande till formstadgade lagkrav och utan inblandning av berörd myndighet. 
enskilda skogsägare (egentligen hemmansägare) och kooperativa förvaltare som allmänningsskogar, kyrkan och liknande.

Förvisso avverkade Domänverket under affärsmässiga former, men driften var underställd förvaltningsmässiga och i grund och botten politiska initiativ att investera i anläggningar, byggnader, vägar, kojor etc. i syfte att utveckla skogsskötseln. Kostnaderna för dessa investeringar visade sig med tiden överstiga inkomsterna från skogsavverkningarna. De enskilda skogsägarna avverkade bara vid behov för att få hem tillräckliga inkomster av de små skogslotter som de hade tillgång till. Men i regel förföll produktionen av timmer även hos dem på grund av sämjedelningen, som inte gav någon avkastning över huvud taget. Ägarna av skogslotterna saknade intresse av, eller kompetens för, att avverka sin del av skogen. De hade bara ärvt lotten och visste inte vad de skulle göra av den. Skogen var ingen kapitalplacering för dessa enskilda skogsägare. Den hade ett högre affektivt än instrumentellt värde för dem.

Dessutom ökade de offentliga tjänsterna (statligt och kommunalt finansierade och underlagda statliga och kommunala direktiv) i omfattning under samma period. Den fria arbetskraften var underlagd statligt ägande av produktionsmedlen. Och i de sektorer där staten (eller kommunen för den delen) inte direkt ägde produktionsmedlen var det staten som ställde upp villkoren (olika bidragsformer, anläggande av infrastruktur och så vidare) för det privata ägandet. Det privata ägandet löd under de ekonomiska villkor som staten godtog utifrån den ekonomiska politik som regeringen ville föra i regionen.

Om det var någon gång i historiens lopp som kapitalismen kan sägas ha slagit igenom i Tornedalen så var det från 1950-talet till ungefär 1970. Skogsbruket anställde helårsvis. Det kvarvarande jordbruket började rationalisera driften genom mekanisering och egenföretagandet ökade i form av snickerier, åkerier och så vidare. Tornedalingen började orientera sitt företagande mot kapitaltillväxt i stället för självhushåll. Det slog hårt mot arbetskraften; rationaliseringar ledde till arbetslöshet vilket slutligen ledde till arbetskraftsmigration till andra regioner i Sverige.

Men samtidigt kvarstod den relativa tillväxten av statliga och kommunala offentliga tjänster, och dessutom minskade inte staten genom Assi sitt skogsinnehav. I själva verket tycks skogsbruket ha drivits av 
arbetsmarknadspolitiska skäl, och överskottet från avverkningarna gick till investeringar i skogsskötselns infrastruktur vilket gjorde att skogsavverkningarna totalt sett var en förlustverksamhet.

Utvecklingen därefter är en utdragen historia om rationaliseringar inom jordbruket och skogsbruket genom ökad mekanisering som ledde till ökat friställande av arbetskraft. Den enda sektor som någorlunda bibehöll sin status som försörjningskälla för den fria arbetskraften var de offentliga tjänsterna. Men även här skedde arbetsrationaliseringar i takt med avfolkningen av regionen. Det hela blev snart nog till en bidragsregion finansierad av skogsmedelsfonder, hushållningssällskap och inte minst statliga medel. Inte ens vid etablerandet av det rent kapitalistiska norsk-kanadensiska gruvbolaget Northland Resources lyckades kapitalismen få fäste mer än lokalt (Pajala kommun) och tillfälligt (2OI2-2OI4).

Vill man vara ironisk, och det kanske man vill, så kom kapitalismen till Tornedalen i bästa fall under 1950-talet. Men den varade inte längre än till 1970 och då kom den ändå inte att dominera som produktionsordning. Dess dominans var lokal och varade inte mer än två år, dock omskriven och fylld med förhoppningar om en växande bygd. Därefter sjönk allt tillbaka, likt ett barn till en moders skyddande famn, till en produktionsordning underlagd det statliga och kommunala förvaltandet av produktionsmedlen. Och där står vi i dag.

\section{Problematiken}

Men låt oss inte stanna vid detta krassa konstaterande. Givet de beroendeteoretiska argumenten så är det inte speciellt svårt att se övre Tornedalen som en satellit till regionmetropolen Norbottens kuststäder, och till den nationella metropolen Stockholm. Det beroendeförhållandet är otvetydigt, men rör det sig om en motsättning mellan centrum och periferi som leder till att övre Tornedalens överskott exproprieras och till att kapitalförhållandet blir den dominerande ordningen i övre Tornedalen?

Svaren på detta beror nog på hur historicistiskt lagd man är som forskare. Om man tror på beroendeteoretikernas tes så kommer man säkert finna bekräftelse på detta. Är man mer naturalistiskt lagd så låter man empirin tala sitt eget språk. Eftersom jag ansluter mig till de senare stäl- 
ler jag mig starkt tvivlande till att det förekom expropriering av överskottet som ledde till underutveckling av regionen. Detta av det enkla skälet att inte fanns något överskott att expropriera, mer än lokalt och under kortare tidsperioder.

När det gäller överförandet av kapitalismens produktionsförhållanden till övre Tornedalen så fanns de otvetydigt i det alltmer utbredda lönearbetet inom skogs- och jordbruket, men det fanns inget expansivt privat eller kooperativt ägande. Skälet till detta är enkelt: om det inte fanns något överskott att expropriera så fanns det helt enkelt ingen expansiv kapitaltillväxt att tala om för ägandet.

Men samtidigt är övre Tornedalen inte någon outvecklad region. I viss kontrast till Franks (1970) argument vill jag mena att regionen utvecklas främst genom statliga initiativ och till viss del genom bildandet av egna kooperationer av olika slag. Det sker en kontinuerlig uppdatering av teknologi och av arbetskraftens kompetens som möter de primära materiella behoven i bygden samt den kapitalistiska produktionsordning som råder i omvärlden. Mitt intryck är att övre Tornedalen överlag tjänar som en "reservgeografi" och i viss utsträckning även som "reservarbetskraft" (i analogi med hur industrin under 1960- och 1970-talen såg på den kvinnliga arbetskraften). Det är en potentiellt exploaterbar resurs som kapitalister (privata såväl som kooperativa) inom den dominerande kapitalistiska produktionsordningen kan ta till när de har behov av att öka kapitalförmeringen. För det är ju så att Tornedalen är underlagd en i övrigt dominerande kapitalistisk produktionsordning i omvärlden. Men så länge det inte finns förutsättningar att exploatera Tornedalens resurser så ligger de vilande i moder Sveas famn.

\section{Referenser}

Alalehto, T. (200I). Tärendö. Historien om en svensk tornedalsby. Kågeröd: Barr.

Amin, S. (1974). Den globala kapitalackumulationen. En kritik av teorin om underutvecklingen. Lund: Zenit.

Bergh, A. (2008). "Hur blev Sverige rikt och jämlikt?", Ekonomisk Debatt, årgång 36, nr 5, s. $4 \mathrm{I}-53$.

URL: http://nationalekonomi.se/filer/pdf/36-5-ab.pdf (I3 december 20I8) 
Dahlgren, L. (1984). Samhällsplanering och lokalsambälle. En sociologisk analys av den sociala sambällsplaneringens möjligheter och begränsningar, illustrerad av tre ortsstudier $i$ Norrbottens län. Umeå: Sociologiska institutionen.

Frank, A. G. (1970). Kapitalism och underutveckling i Latinamerika. Historiska studier över Chile och Brasilien. Staffanstorp: Cavefors.

Från Junaswa till Junosuando (2000). Lidingö: Junosuando byaforskningsgrupp.

Hanno, C.-U. (1977). Vittangi. En bok om en livskraftig bygd. Vittangi: Vittangi hembygdsförening.

Hansen, P., Hultberg, P.-O. \& Söderlund, L. (1976). Svensk kapitalism. En studie $i$ Sveriges ekonomiska historia. Göteborg: Röda bokförlaget.

Ingham, G. (2013). Capitalism. With a new postscript on the financial crisis and its aftermath. Cambridge: Polity (e-bok).

Kaunisvaara I800-2000 (200I). Pajala: Kaunisvaara byaförening.

Lundmark, L. (1985). Protest och profetia. Korpela-rörelsen och drömmen om tidens ände. Lund: Arkiv förlag.

Magnusson, L. (2002). Sveriges ekonomiska historia. Stockholm: Prisma.

Marx, K. (2013). Kapitalet. Kritik av den politiska ekonomin. Bok I, Kapitalets produktionsprocess. Lund: Arkiv förlag (6 uppl.).

Minnen och episoder från sjukstugan och ålderdomshemmet $i$ Övertorneå. Del I (1995). Övertorneå: ABF.

Mäkipiha, E. (2007). Skogarnas folk. Berättelser frän Tornedalen. Överkalix: Barents.

Nordin, S. (198I). Historia och vetenskap. En essä om marxismen, historicismen och humaniora. Lund: Zenit.

Olofsson, S. S. \& Greiff, M. (2010). Hembygdshistorik om Männikkö-Vaenvaara. Byar i Pajala kommun, Tornedalen, Norrbotten, Sverige. Malmö: Malmö högskola.

URL: http://muep.mau.se/handle/2043/I0828 (I3 december 20I8)

Popper, K. (2002). Historicismens elände. Göteborg: Daidalos.

Ridbäck, I. (20I5a). Korpilombolo. Från kyrkobygge till nattfestival. Uppsala: IR-text.

Ridbäck, I. (20I5b). Narken - Narkaus. En by norr om Polcirkeln. Uppsala: IR-text.

Schön, L. (2007). En modern svensk ekonomisk historia. Tillväxt och omvandling under två sekel. Stockholm: SNS förlag.

SKS (1982). Skogsstatistisk årsbok. I980. Jönköping: Skogsstyrelsen.

SOS (I923). Jordbruk och boskapsskötsel. År I920. Stockholm: Statistiska centralbyrån, Sveriges officiella statistik.

SOS (1938). Skogsbygdens arbets- och levnadsvillkor. Del I, Undersökningens huvudresultat. Stockholm: Socialstyrelsen, Sveriges officiella statistik.

SOU 1958:22. Tornedalsutredningen. Del I, Grundläggande undersökningar. Stockholm: Socialdepartementet.

SOU 1960:37. Tornedalsutredningen. Del 2, Förslag till åtgärder för näringslivets utveckling. Betänkande. Stockholm: Socialdepartementet.

Wallerstein, I. (20II). The modern world-system II. Mercantilism and the consolidation of the European world-economy, I600-I750, with a new prologue. Berkeley: University of California Press (e-bok). 
ALALEHTO | NÄR KOM KAPITALISMEN TILL TORNEDALEN?

Weber, M. (1986). Kapitalismens uppkomst. Stockholm: Ratio.

Öström, K. (1980). Blandekonomi, statskapitalism eller militant regionalism. Hur ska vi egentligen ha det i Norrbotten under I980-talet? Luleå: Skrivarförlaget och Norrbottens bildningsförbund. 


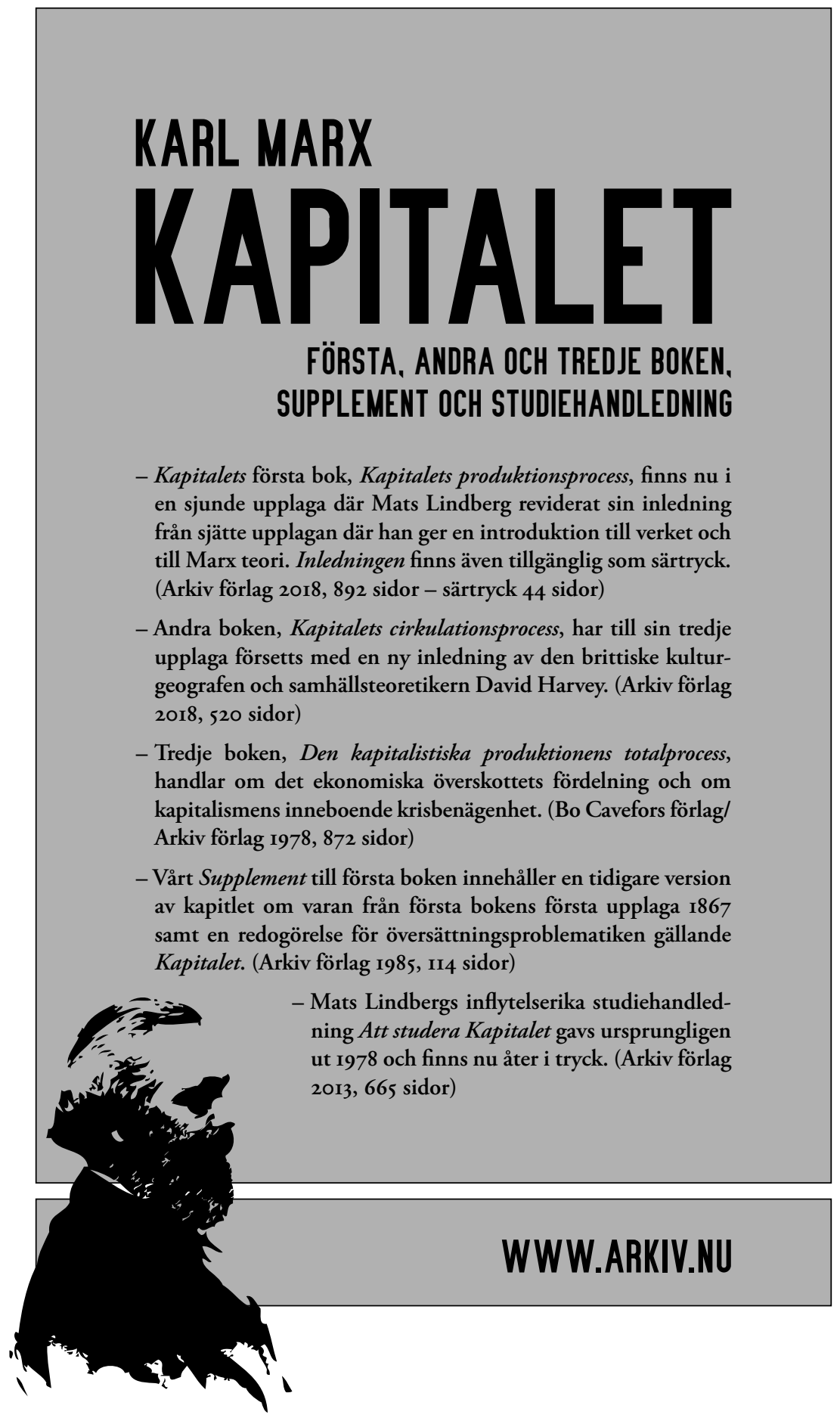

